\title{
Which Approach to Justice in Colombia under the Era of the ICC
}

\begin{abstract}
How could Colombia deal with the overwhelming cruelty of mass atrocities committed during its ongoing conflict? This article intends to thoroughly explain the strategies implemented in Colombia to deal with the issues of transitional justice in an ongoing conflict and to illustrate the state of the art of the approaches to justice. In order to do so, we will show the limits of the retributive justice approach at both the national and the international level and propose the applicability of the restorative justice approach in dealing with mass victimisation in dealing with past crimes. This debate becomes even more complex due to the shadow of the International Criminal Court (ICC), which has exerted great influence in implementing a dominant retributive oriented approach to the expenses of other ways of doing justice.
\end{abstract}

\section{Keywords}

retributive justice; restorative justice; Colombia; transitional justice; International Criminal Court (ICC)

\section{Introduction}

For more than five decades the Colombian society has experienced a devastating conflict that has implied millions of victims of serious violations of human rights such as torture, massacres, kidnapping, forced displacement, child recruitment, among others. Behind these atrocities are thousands of offenders, many of whom have already demobilized either collectively or individually. ${ }^{1}$ Despite the ongoing conflict, and for the first time in its history, ${ }^{2}$ Colombia implemented State organized transitional justice mechanisms to deal with the consequences of mass

\footnotetext{
1) Agencia Colombiana para la Reintegración, Desmovilización, <www.reintegracion.gov.co>, 10 January 2012.

2) In the words of Gomez, "in previous peace processes in Colombia, crimes against humanity have never been prosecuted, the victimizers have never been required to confess, even negligibly, to the truth of their crimes, nor have the victims and their right to reparations been taken into consideration". Felipe Gómez, 'Challenges for Transitional Justice in Contexts of Non-transition: The Colombian Case', in Michael Reed and Amanda Lyons, (eds.), Contested Transitions: Dilemmas of Transitional Justice in Colombia and Comparative Experience (International Center for Transitional Justice, Bogota, 2010).
} 
atrocities; Law 975, better known as the Justice and Peace Law (JPL), was enacted into law by the president on 25 July 2005 to "ease the peace negotiations with the armed groups and the individual and collective reincorporation of the members into civil life, guaranteeing that the victims will have the right to truth, justice and reparation". ${ }^{3}$

This law, which did not go without thorny controversy, ${ }^{4}$ established the legal framework for members of paramilitary and guerrilla groups responsible for the violations of human rights, who were not granted amnesties and pardons through Law 1106 of 2006. ${ }^{5}$ Unlike the ordinary Colombian penal code, which prescribes prison sentences that could go up to 60 years, the JPL offers a reduced alternative prison sentence. In sum, as Lyon notes, the JPL establishes "a confessional criminal justice model that offers willing candidates significant reduced sentences (five to eight years in prison) in exchange for satisfaction of several conditions, including cessation of criminal activity, full confession to past crimes, and submission of all personal assets for victim reparation". ${ }^{6}$

Besides these criminal proceedings, the JPL created a particular commission, the National Reparation and Reconciliation Commission (CNRR), whose main guiding principle "is to take care of yesterday's victims so as to prevent tomorrow's victims". ${ }^{7}$ Furthermore, reparative procedures such as the administrative reparation and the historical Victims' Law, as well as a consolidated disarmament, demobilization and reintegration (DDR) process have also been implemented in Colombia.

Certainly, the overwhelming cruelty and massive scale of the crimes committed in the conflict has posed various obstacles to the effective administration of these mechanisms, which raises the question of the adequate approach to deal with past crimes. In its effort to find a balance between justice and peace, Colombia has implemented various transitional justice mechanisms that have been influenced by the retributive approach due to the current paradigms of justice at the international level. In fact, these paradigms have done such much emphasis on retributive justice that they prevented other ways of dealing with mass atrocities, like the one offered by the restorative justice approach.

\footnotetext{
3) Article 1 of the Justice and Peace Law, Law 975 of 25 July 2005.

4) Eduardo Pizarro and León Valencia, Ley de Justicia y Paz (Cara \& Sello, Grupo Editorial Norma, Bogota, 2009).

5) Law 1106 of 2006, which extended the effects of Law 782 of 2002, granted amnesty to the demobilized members of illegal armed group who did not had criminal charges.

6) Amanda Lyons, 'For a Just Transition in Colombia', in Michael Reed and Amanda Lyons, (eds.), Contested Transitions: Dilemmas of Transitional Justice in Colombia and Comparative Experience (International Center for Transitional Justice, Bogota, 2010).

7) Eduardo Pizarro 'Justice, truth and reparation law and its impact on the peace processes in Colombia', in Colombia: Peace Processes and their Legal Framework (EPP-ED Group in the European Parliament, Brussels, 2005), p. 18.
} 
As a matter of fact, the role of the International Criminal Court (ICC or the Court) in Colombia has made this debate even more complex due to the delicate correlation between national mechanisms of justice and the jurisdictional role of the ICC. In fact, since the court is one of the main representatives of the retributive justice approach when dealing with past crimes, it has established limitations regarding other approaches to justice like the restorative one.

This article intends to illustrate the state of the art of the retributive and the restorative approach to justice in Colombia. In order to do so, we will first of all give a brief overlook to the Colombian conflict and legal tradition. Secondly, we will explain the strategies that have been used to deal with the crimes of the ongoing conflict, showing the limits of the retributive justice approach at both the national and international level, and finally, we will explore the applicability of the restorative justice approach in dealing with mass victimisation under an era governed by the shadow of the ICC.

\section{The Colombian Conflict}

Colombia is currently on the process of establishing the grounds of its transition after more than 50 years of violence. In fact, it is one of the three more extended ongoing conflicts in the world, in which "violence has become the reference point for Colombian politics, society, and economy" ${ }^{8}$

One of the first landmarks of this long lasting conflict is the period known as "La Violencia" (1946-1953): an episode of the Colombian history marked by regional clashes between two political parties, the Liberals and the Conservatives, and symbolized by the murder of the liberal leader Jorge Eliecer Gaitán which took place on the unforgettable 9 April 1948. It is estimated that between 1946 and 1953, 200,000 persons were killed in the confrontations between liberal selfdefense groups and counter insurgent Conservatives militias. ${ }^{9}$ The inability of the civilian leaders to deal with rural violence and their own political disputes allowed General Rojas Pinilla to lead a coup d'état in 1953. Four years later, a pact was signed between these two traditional parties, removing Rojas Pinilla and giving rise to the National Front (1958-1974): an alliance that lasted 16 years during

\footnotetext{
8) Gonzalo Sánchez, 'Problems of Violence, Prospects for Peace', in Charles Bergquist et al. (eds.), Violence in Colombia, 1990-2000: Waging War and Negotiating Peace (Scholarly Resources Inc., Wilmington, 2001) pp. 1-38.

9) Fernán González, Conflicto Violento en Colombia: Una perspectiva de largo plazo, <www.google .com/url?sa=t\&rct=j\&q=la\%20violencia\%201946\%201953\%2C\%20200\%2C000\%20muertos $\% 20$ colombia\&source =web\&cd=4\&ved=0CD8QFjAD\&url=http\%3A\%2F\%2Fcmap.upb.edu .co\%2Frid\%3D1144355653250_1241055914_694\%2FConflictoViolentoColombiaFernanGon zalez.doc\&ei=ydtDT8H6LozvggeEy92nCA\&usg=AFQjCNGLUV8m0g9SHD4GAE-NUFUQY g9CKw\&sig2=BfMvkz4PiRegyJdkta-OUw>, 15 December 2011.
} 
which Liberals and Conservatives intercalated the presidency and other governmental positions.

However, in spite of the general stability triggered by the National Front, various parties felt excluded from the political scenario. In addition to such exclusion, the emergence in the 60s of Cuban-style communism and social revolutionary ideologies contributed to the consolidation of left-wing revolutionary guerrillas groups such as the National Liberation Army (ELN-1964), the Revolutionary Armed Forces of Colombia (FARC-1966), the Popular Liberation Army (EPL1967) and the $19^{\text {th }}$ of April Movement (M19 - 1970), among others.

During the 1970s, the Colombian society went through diverse processes of transformations that made evident the obsolescence of official institutions. The weak Colombian State was ineffective to deal with these social changes and the emergent popular claims for land distribution and social justice continued being ignored by the government.

The fight of guerrilla groups against the government and civilians triggered the emergence of the paramilitaries in the 80s. These groups emerged initially in Antioquia, the Caribbean Coast and the Valle and particularly expanded after the year 1984. Lately, in 1997, under the leadership of Carlos Castaño, they became a structured and extensive organization known as the Autodefensas Unidas de Colombia (United Self-Defense Forces of Colombia, AUC). ${ }^{10}$

The decades of the 1980s and the 1990s were marked by relevant processes of negotiations and peace accords with guerrilla groups. As a result, various demobilized guerrilleros were offered the opportunity of participating into society in a democratic way, particularly in the National Constituent Assembly, which resulted in a new Colombian Constitution promulgated on 4 July 1991. But still, in spite of this fruitful sequence of peace events, Colombia missed a historical opportunity to achieve peace through the assassinations and disappearances of the members of the Patriotic Union, a coalition of communist-socialist tendency product of previous guerrilla's demobilizations. Undoubtedly, this tragic event compromised further negotiations with the guerrillas, ${ }^{11}$ notably with the FARC and the ELN, that are still operating today.

The attempt of achieving peace was also intended by President Pastrana (19982002) when offering an area of $42.000 \mathrm{~km} 2$ to the guerrilla of the FARC: a demilitarized Colombian territory, known as "El Caguan", totally submitted to the rules of the illegal organization. Despite this generous presidential effort, the FARC continued committing mass atrocities on a daily basis. As a result, in February 2002, Pastrana announced the definitive breaking off of the peace process with the FARC and put an end to the demilitarized region.

10) Fernán González, 'The Colombian Conflict in Historical Perspective', 14 Accord, An International Review of Peace Initiatives (2004) 10-17.

11) Sánchez, supra note 8. 
It was in this context marked by profound disillusionment and even rage that Colombians elected President Alvaro Uribe Velez (2002-2012) on a military platform. Uribe changed the dynamic of the negotiations combining it with a hard-line militaristic approach, ${ }^{12}$ characterized by the implementation of the "democratic security" policy, which involved an intensification of the military response against the guerrilla groups. ${ }^{13}$ In fact, unlike the FARC and the ELN, the AUC did not take long to initiate a peace agreement with the Uribe administration that led to the signing of the San José de Ralito agreement in 2003, and according to which the members of the AUC accepted to demobilize in exchange of appropriate mechanisms designed to deal with their legal status and processes of reintegration. This peace agreement, whose exact terms and conditions remain unknown, led to the demobilization of more than 30,000 paramilitaries. However, the number of demobilized ex-combatants increments on a daily basis due to the individual demobilizations of ex paramilitary and guerrilla members.

In addition to the complexity triggered by the illegal armed groups, the Colombian conflict has been terribly affected by the traffic of drugs; the economy produced by this profitable business has transformed the conflict, consolidating different forms of power that involves both paramilitary and guerrilla members, but also regional and national political and military authorities..$^{14}$

It is in this complex context of ongoing conflict that Colombia implemented State organized transitional justice mechanisms.

\section{Transitional Justice}

Transitional justice implies rethinking the way to end conflicts and the type of strategies for post-conflict or post-authoritarian reconstruction. It refers, in fact to "the full range of processes and mechanisms associated with a society's attempts to come to terms with a legacy of large-scale past abuses, in order to ensure, accountability, serve justice and achieve reconciliation". ${ }^{15}$ This definition involves a number of elements, such as, truth seeking, accountability, reparation

\footnotetext{
12) Cynthia Arnson et al., Los procesos de paz en Colombia: Múltiples negociaciones, múltiples actores (Woodrow Wilson International Center for Scholars, Washington, D.C, 2007).

13) Marc Chernick, Acuerdo Posible. Solución negociada al conflicto armado colombiano (Ediciones Aurora, Bogota, 2008).

14) This phenomenon known as "Parapolitica" (Parapolitics) showed its real dimension when in 2005 the existence of these connections was disclosure and investigations against 102 members of the Congress began. Claudia López, "'La Refundación de la Patria”, De la Teoría a la Evidencia', in Claudia López, (ed.), Y refundaron la patria... De cómo mafiosos y politicos reconfiguraron el Estado colombiano (Debate, Bogota, 2010).

15) Report of the Secretary-General to the Security Council of the United Nations, The rule of law and transitional justice in conflict and post-conflict societies (S/2004/616).
} 
and reconciliation, which scholars have considered relevant when analysing transitions. ${ }^{16}$

From the Nuremberg trials to the creation of the ICC, the question of "transitional justice" has been shaped by various approaches and mechanisms. In fact, the complexities and unique characteristics of each war-torn society encourage a rich variety of mechanisms to the expenses of a unique globalized mechanism of transitional justice.

By dealing with such wide-ranging human issues, transitional justice is by nature a multidisciplinary field of study. In the words of Kritz,

projects on justice and reconciliation in the aftermath of mass abuses have proliferated at universities and think tanks. It has become a topic of inquiry in a variety of disciplines, including law, philosophy, sociology, political science, theology, anthropology and the arts. ${ }^{17}$

Interestingly though, despite the important role played by TRC and local-level mechanisms, amongst others, the field of transitional justice has been mainly tainted by a legalistic vision of justice, particularly at the international sphere. In fact, as Liwerant rightly notes, "with the exception of juridical and historical works, social sciences barely considered collective murders until the turn of the 21 st century". ${ }^{18}$ This pre-eminence of the legal dimension it is also evident in the configuration and development of the field, ${ }^{19}$ especially if we take into account that it is based on the idea of introducing legal constraints to transitions.

The dominant role of international law in the literature and practice of transitional justice has not gone without controversy and disputes with other disciplines that share different interests than those promoted by law. For example, Lambourne explains how "the efforts of international lawyers and human rights advocates to fairly and justly prosecute those responsible for perpetrating crimes against humanity, and to ensure a future respect for the rule of law and human rights principles, are juxtaposed against the efforts of international peace negotiators and conflict resolution practitioners who prioritize the establishment of peace and security and a climate of reconciliation between former enemies". ${ }^{20}$

16) Ruti Teitel, Transitional Justice (Oxford University Press, New York, 2000). Also see: Stephan Parmentier, 'Global Justice in the Aftermath of Mass Violence. The Role of the International Criminal Court in Dealing with Political Crimes', 41 1-2 International Annals of Criminology (2003) pp. 203-224.

17) Neil Kritz, 'The Legacy of Abuse: Confronting the Past, Facing the Future' in Alice H. Henkin (eds.), Where We Are and How We Got Here: An Overview of Developments in the Search for Justice and Reconciliation (New York University School of Law, New York, 2002).

18) Sara Liwerant, 'Mass Murder: Discussing Criminological Perspectives', 5 Journal of International Criminal Justice (2007), pp. 917-939.

19) Ruti Teitel, 'Transitional Justice Genealogy', 16 Harvard Human Rights Journal (2003), pp. 69-94.

20) Wendy Lambourne, 'Transitional Justice and Peacebuilding after Mass Violence', Seminar Presentation, Centre for Peace Research and Strategic Studies (K.U. Leuven, Leuven, 2006). 
The duel between international lawyers and conflict resolution practitioners deeply touches the very particular transitional process of Colombia. As we will see, retributive approaches, particularly the threat of being prosecuted by the ICC, may pose serious obstacles to the peace and reconciliation process in Colombia.

In addition, this legal dimension of transitional justice is not yet fully consolidated; there is in fact an ongoing tension between legal standards coming from international law and the practices of States during transitions. ${ }^{21}$ On the one hand, international legal standards came from the development of different branches of international law, in what Bell calls a "regime merge" of international human rights law, international humanitarian law and international criminal law. ${ }^{22}$ On the other hand, the national practice is characterized by practical considerations when governments have to deal with dilemmas in these periods.

The product of this tension is a range of possibilities between two extremes, where it is possible to find a discourse of "human rights respect as a synonym of retribution" and more "alternative measures related to the seeking of truth". These two "models" are often presented as the unique alternatives for transitional measures. ${ }^{23}$

The "human rights respect as retribution" discourse places significant emphasis on accountability as a synonym of criminal procedures. ${ }^{24}$ The relevance it has acquired can be seen by the large institutionalisation and widespread legal and economic support for retributive mechanisms worldwide. This trend is influenced by the experience of the Nuremberg and Tokyo trials, the Ad-Hoc International Criminal Tribunals for Rwanda and the Former Yugoslavia, the International Criminal Court, the internationalised courts of Sierra Leone, Kosovo, Timor-Leste and Cambodia and the domestic trials that have taken place in different parts of the world. ${ }^{25}$

On the other side we find "other alternative measures" to respond to past abuses which involve a broader understanding of justice and the possibility of using diverse mechanisms to deal with the past. Consequently, it is possible to introduce a certain degree of flexibility to the common belief that criminal prosecutions are the only way to obtain accountability.

21) Christine Bell, On the Law of Peace. Peace Agreements and Lex Pacificatoria (Oxford University Press, Oxford, 2008).

22) Ibid.

23) Kieran McEvoy, 'Letting go of legalism: Developing a "Thicker" version of Transitional Justice', in Kieran McEvoy and Lorna McGregor (eds.), Transitional Justice from Below: Grassroots Activism and the Struggle for Change (Hart Publishing, Oxford, 2008).

24) Luc Huyse, 'The Process of Reconciliation', in David Bloomfield et al. (eds.), Reconciliation after Violent Conflict. A Handbook. (IDEA, Stockholm, 2003).

25) Rachel Kerr and Eirin Mobekk, Peace and Justice. Seeking Accountability after War, (Polity Press, Cambridge, 2007). 
Thus, as we have previously explained, there is not only a preeminent legalistic understanding of transitional justice but also a retributive view of it. The criminal and prosecutorial character that transitional justice has adopted can be observed in the multiplication of international bodies in charge of prosecuting grave human rights violations, the international community's pressure for the application of international human rights standards and the consolidation of international crimes as a consequence of the ICC's creation. ${ }^{26}$ At the national level, there have been cornerstone cases like the judgment of the former Peruvian president Alberto Fujimori and the numerous national prosecutions in Colombia.

Since the retributive approach has dominated the transitional justice field, Colombia has considered mandatory to comply with its legal international obligations. However, as previously noted, there are other visions of justice, such as the restorative one, that really questions the assimilation of justice to the retributive approach.

\section{The Legal Framework for Dealing with Massive Crimes in Colombia}

The Rome Statute that created the International Criminal Court entered into force in 2002. In fact, such creation was the more visible effort of the international community towards prosecuting international crimes. The beginning of its operations showed that the Court was a reality and it made imminent for many States the necessity of adapting their criminal policies to comply with the Court's standards.

Also in 2002 the Colombian government started to implement transitional justice mechanisms as an effort to bring to an end a conflict that has lasted for more than 50 years and that has caused thousands of victims of the most atrocious crimes. The Colombian government began peace negotiations with the AUC and started to design the legal framework for their demobilization.

These two events intersected each other generating multiple relations and effects between them. On the one hand, since 2005 the ICC has maintained a permanent evaluation of the Colombian situation, which became even stronger with the opening of the preliminary examination in 2006. On the other hand, the Colombian government has actively reacted to the Court's claims, implementing a national policy to respond to these demands.

These two interrelated normative levels constitute the framework of retributive justice in Colombia that we will analyze, making a critical assessment of its achievements and deficiencies.

\footnotetext{
26) Naomi Roht-Arriaza, 'Mass Murder: Discussing Criminological Perspectives State Responsibility to Investigate and Prosecute Grave Human Rights Violations in International Law'. 78 California Law Review (1990).
} 


\subsection{The National Level: Pardons and Trials}

Colombia has an old legacy of solving conflicts through negotiations and amnesties. It has involved solutions based only on political considerations, generally conferring pardon to the conflictive parts. ${ }^{27}$ However, the influence of criminal justice on the international scene has changed this tendency. There are in fact, other considerations that prevent general and unconditional pardons to achieve peace and a requirement to prosecute the gravest crimes.

In the next part we will analyze the Colombian legal tradition, how it has changed in the last decade and the current situation of the implementation of retributive-criminal justice mechanisms.

\subsubsection{The Colombian Legal Tradition}

By the end of the 1980s and during the 1990s, the government engaged in many negotiations with the illegal armed groups. The majority of these agreements did not include any obligation regarding reparations to victims, the search of truth and the administration of justice. In fact, they only considered judicial benefits for those who decided to demobilize. ${ }^{28}$

Thus, in 1989, the government reached an agreement with the M-19, offering them an amnesty through Law 77 of 1989. In the same line, during the first years of the 1990s, the Colombian government established a set of norms to cover the demobilization of different armed groups. Based on that framework, in 1991 the Ejército Popular de Liberación (EPL), the Partido Revolucionario de los Trabajadores (PRT) and the Movimiento Armado Quintin Lame (MAQL) decided to demobilize after a peace accord with the government. ${ }^{29}$

After this process the new Constitution of 1991 was enacted, including important social reforms brought forward by ex members of these groups. The Constitution also included the power of the Executive and the Legislative branches to grant pardons and amnesties. In 1992 the Comandos "Ernesto Rojas" signed a peace accord under Decree 1943 of 1991. In 1993, the government enacted Law 104 that established the extinction of the action and the criminal penalty, as a background for the demobilization in 1994 of the Corriente de Renovación Socialista (CRS), the Milicias Urbanas de Medellin and the Frente Francisco Garnica de la Coordinadora Guerrillera (FFG). Finally, in 1998 the government reached an agreement with the MIR-COAR armed group under

\footnotetext{
27) Carlos Alberto Mejía, 'Aproximación a los instrumentos jurídicos aplicados a los procesos de “negociación de la paz" en Colombia', 2 CES Derecho (2011) pp. 58-71.

28) Ibid.

29) Decree 213 of 1991 also covered their disarmament.
} 
Law 418 of 1997 that established grounds for the extinction of the criminal action and penalty in political and related crimes. ${ }^{30}$

As it is possible to observe, the general pattern of these agreements was not the prosecution of perpetrators. These norms usually ended or prevented any type of prosecution against the demobilized and excluded some crimes, known in Colombia as acts of "ferocity and barbarity", which involved crimes such as kidnapping, murder committed outside combat or crimes committed putting the victim in a defenceless situation. ${ }^{31}$ However, it is not clear until which point investigations were conducted to establish whether or not the beneficiaries of pardons committed those crimes.

In the last years the possibility of granting pardons have suffered limitations with the arising of transitional justice and what some have called the "new humanitarian conscience", which makes a pure negotiated solution impossible. ${ }^{32}$ According to this new scenario, it is not possible to confer pardon to perpetrators of grave crimes (mainly international crimes).

Colombia has accommodated to this scenario by gradually introducing international law into its national legal culture. In the last years, and probably as a consequence of the expansion of the "global transitional justice" discourse, ${ }^{33}$ governmental and non-governmental actors in Colombia have learnt the transitional justice and International Law paradigms and have started to apply them in their institutions and mechanisms. The interviews conducted in Colombia with representatives of the executive and the judiciary brands showed their high level of knowledge of transitional justice theory and terminology. ${ }^{34}$ Such knowledge was also manifested on the way in which the government introduced transitional justice as an instrument to deal with mass victimization committed in the country. Furthermore, the transitional justice language was also used by opposing groups to challenge the government's discourse.

In this particular context, which was the product of diverse legal transformations, began the negotiations between the Colombian government and the AUC, leading to the necessity of creating a new legal framework.

\footnotetext{
30) Report on the demobilization process in Colombia. OEA/Ser.L/V/II.120, Doc. 60, 13 December 2004.

31) These crimes are included in the text of article 127 of the Colombian Criminal Code that has ruled the exclusion of atrocious crimes from political crimes.

32) Ivan Orozco, Sobre los Limites de la Conciencia Humanitaria. Dilemas de la Paz y la Justicia en América Latina (Editorial Temis - Universidad de los Andes, Bogota, 2005).

33) Ruti Teitel, 'Global Transitional Justice', Working Paper No 8 (Center for Global Studies, George Mason University, Fairfax, 2010).

34) These interviews were conducted with representatives of the government during the fieldwork developed in Colombia between October 2010 and March 2011. Andrea Diaz's doctoral thesis (unpublished work).
} 


\subsubsection{The Current Legal Framework for the Demobilization}

The legal framework of the demobilization has its origins in the processes of negotiation, demobilisation and reinsertion of the armed actors of the conflict. It is based on two legal regimes that clearly reflect the mixture of the pardon and retributive-criminal approaches, as a result of the influence of the transitional justice discourse.

The first legal framework is the one of Law 1106 of 2006 and its decrees. This legal regime is applicable to members of the illegal groups who have declared not to have committed grave crimes. Given the absence of prosecutions, we could assimilate this legal framework to the Colombian pardon tradition previously exposed.

The second legal regime is the one of the Justice and Peace Law of 2005, read in conjunction with the Constitutional Court rulings C-370 and C-570 from 2006 and the decrees created for its application. According to this law, those ex combatants who committed grave crimes and accord to demobilize must be prosecuted in exchange of reduced sanctions. This legal framework is influenced by the new trend of transitional justice and International Criminal Law that require prosecution for international crimes.

Both regimes have been applied in the current process of demobilization in Colombia, offering a complex legal framework that shows the interrelation of different visions of justice. Law 418 of 1997, and whose effects have been extended through Law 548 of 1999, Law 782 of 2002 and Law 1106 of 2006 (with effects until December 2010). ${ }^{35}$ These norms establish administrative measures that should be taken under the supervision of the Executive power and applied to the demobilization process of ex combatants who are not under prosecution and have not been convicted, or declared not to have committed crimes that "according to the Constitution, the law, or international treaties signed and ratified by Colombia are ineligible for this class of benefits" ${ }^{36}$

Law 418 of 1997, whose effects were extended by Law 548 of 1999, opened the possibility for a dialogue between the State and members of illegal groups having a political status. In fact, this legal framework was applied to the peace negotiations that took place in the 90s between the government and the FARC, but which unfortunately failed.

Furthermore, the Uribe administration extended the effects of this legal framework through Law 782, promulgated on 23 December 2002, only two days after

35) These laws have been implemented through the following decrees: 128 of 2003, 3360 of 2003 and 2767 of 2004.

36) Article 21 of Decree 128. 
the paramilitary groups decided the unilateral cessation of hostilities. However, this new regulation did not require the recognition of a political status of the illegal groups to begin a negotiation.

Law 782 prescribed an official pardon for those who had been part of an illegal group but who were not involved in the commission of grave crimes. ${ }^{37} \mathrm{In}$ fact, the crimes covered by this legal framework were rebellion, treason and riot and the benefits included freedom of prosecution (amnesty or pardon) and access to the social and reintegration programs of the government. ${ }^{38}$

However, the absence of meaningful testimonies and deep investigations allowed an important percentage of the demobilizations to take place without establishing whether those persons had committed or not grave crimes ${ }^{39}$ Since the verification was done only considering the absence of criminal imputations on the official records and a personal statement declaring so, there is no certainty if the demobilized were involved or not in the commission of grave crimes. ${ }^{40}$ Some critics consider that this process produced de facto and general amnesties. In addition, the lack of real control has also allowed many persons, who didn't belong to the demobilized groups, to participate in the process and many real combatants of these groups to be excluded. ${ }^{41}$

In that regard, the Inter-American Commission on Human Rights (IACHR) has affirmed that these norms,

should not by themselves pose a legal obstacle to investigating crimes against humanity or grave violations of human rights, and the waiver of prosecution contained in that legislation does not have the effect of res judicata with respect to criminal investigations that may be opened in the future. ${ }^{42}$

37) This norm was regulated by Decree 128 of 2003. It offers detailed information regarding the proceedings and organisms to carry on the demobilization and reintegration of those individuals who agree to demobilize.

38) The effects of this law were later extended through Law 1106 of December 2006 until 21 December 2010. To cover the extent number of demobilizations that took place out of this period, the Colombian government enacted Law 1424 of 2010, which gives legal benefits to people who were demobilized from illegal armed groups, so they can preserve their freedom, if they comply with the commitments of their reintegration process (stop committing crimes, tell the truth to contribute to the historical clarification and to specific facts and participate of the reintegration activities). According to the director of the Colombian Agency for Reintegration, almost 21500 ex-paramilitary members had applied for benefits under this law. This law was in force until 28 December 2011.

39) Some data mentioned that $87 \%$ of the 35000 demobilizations took place under this regime. Other sources consider that it has covered almost the $92 \%$ of the total number of demobilizations. FIDH, Colombia, la desmovilización paramilitar, en los caminos de la Corte Penal Internacional (FIDH, Paris, 2007) pp. 17-18.

40) According to Decree 128, the criteria required to be included under this legal framework were the absence of criminal records and a certificate issued by the Weapons Surrender Committee (CODA), Article 13 of Decree 128.

41) Report on the implementation of the Justice and Peace Law: Initial stages in the demobilization of the AUC and first judicial proceedings. OEA/Ser.L/V/II.129, Doc 6, 2 October 2007, para. 39.

42) Ibid., para. 42. 


\subsubsection{The Justice and Peace Law Regime}

The second element of the Colombian demobilization legal framework is based on the Justice and Peace Law - Law No 975 of 25 July 2005. In contrast to Law 1106 's regime, this norm called for criminal prosecutions, clearly showing the influence of retributive justice in the implementation of transitional justice in Colombia. ${ }^{43}$

Basically, the Justice and Peace law granted significantly reduced prison sentences to members of illegal armed groups who have agreed to demobilise and who were involved in grave human rights violations. The law conditions the grant of these benefits to the disclosure of the full truth about past crimes, the devolution of illegally obtained goods to compensate the victims and the compromise to not commit new crimes. ${ }^{44}$

As we mentioned before, this norm was designed in the context of a society trying to pass from conflict to peace; consequently, the process was carried out without a clear legal framework. In fact, Law 975 was drafted and discussed while the government was negotiating the ceasefire and demobilization process of the AUC. At the same time, the ICC was starting its operations, a situation that imposed serious considerations and limits to the content of the future norm.

The first draft of the law presented by the government in August 2003 was the Ley de Alternatividad Penal (The Alternative Sanction Law). This draft did not guarantee the rights to reparation, truth and justice of the victims and contained an evident unbalance between the lenient punitive benefits for the perpetrators and the lack of protection and effective mechanisms to protect the victims' rights. As a result, the proposal was hardly criticized by the Congress and the civil society, and finally, withdrawn by the government.

Nevertheless, the core of this first draft was maintained in the future debates on the law: the possibility of giving disproportionately reduced sanctions to perpetrators of grave crimes, an idea that combined plea bargain/pardon and retributive models of justice. In fact, whereas the bargain/pardon model was already part of the Colombian legal culture to end conflicts and negotiate peace, the retributive one was reinforced by the international trend that supports the use of retributive criminal justice for mass victimization. ${ }^{45}$

43) Felipe Gómez, 'Global Transitional Justice Justicia, Verdad y Reparación en el Proceso de Desmobilización Paramilitar en Colombia', in Felipe Gómez (eds.), Colombia en su laberinto. Una mirada al conflicto (Catarata, Madrid, 2008).

44) Comisión Colombiana de Juristas, Anotaciones sobre la ley de justicia y paz. Una mirada desde los derechos de las víctimas (Comisión Colombiana de Juristas, Bogotá, 2007).

45) This approach is supported by the Inter-American system of human rights, of which Colombia is part, since it deems criminal prosecution as the way to comply with State obligations under the American Convention on Human Rights. See: Inter-American Court of Human Rights: The Case of Velasquez-Rodriguez v. Honduras, 29 July 1988, Inter-Am. Ct. H.R., Series C, No. 4, para. 134; Inter-American Court of Human Rights: The Case of Godinez-Cruz v. Honduras, 20 January 1989, Inter-Am. Ct. H.R., Ser. C, No. 5, para. 175; Inter-American Court of Human Rights: The Case of 
Law 975 needs to be read in association to the Constitutional Court's decision of 18 May 2006 (C-370/06) that changed the interpretation of many of its articles, the jurisprudence of the Supreme Court and the Decrees ${ }^{46}$ that implement the law. However, the application of the law to nearly 4346 ex members of illegal groups who had applied to the process should also be taken into account in order to fully understand it. ${ }^{47}$

On the one hand, The Constitutional Court's jurisprudence included parameters of interpretation to protect victims' participation in the process and their access to full reparations. Furthermore, Decision C-370/06 also clarified the obligation to enforce the sanction, established the consequences inflicted if the applicants kept information from the authorities and better regulated the deadlines to complete judicial proceedings. ${ }^{48}$ On the other hand, the Supreme Court ruled about the lack of political status of paramilitary groups, ${ }^{49}$ it also established the procedural requirements for the incidental issue of reparation, ${ }^{50}$ it banned from handing out partial charges derived from incomplete confession $s^{51}$ and it established victims' rights as the core of the whole process. ${ }^{52}$

These modifications transformed the Justice and Peace Law, showing how check and balances work in the Colombian society. Even though this is a positive feature that reflects a dynamic democracy, it also shows the lack of a clear strategy and single objective on the law's application. In fact, on the one hand, during the process of creation of the norm, different actors added diverse, and sometimes contradictory elements to the law and, on the other hand, during its application each institution understood and implemented different modus operandi, according to their particular understanding of the law and their own goals and interests.

The lack of consensual strategy has posed a lot of problems on the application of the law and has caused the delay on the achievement of results. Furthermore, it has taken a long time to establish a coordinated and linked response on the way the law had to be applied.

Paniagua-Morales v. Guatemala, 8 March 1998, Inter-Am. Ct. H.R., Ser. C, No. 37, T I; InterAmerican Court of Human Rights: The Case of Barrios Altos v. Peru, 14 March 2001, Inter-Am. Ct. H.R., Ser. C, No. 75.

46) These are Decree 4760 of 2005, Decree 2898 of 2006, Decree 3391 of 2006, Decree 4417 of 2007, Decree 315 of 2007 and Decree 23 of 2007.

47) Presidencia de la República, La desmovilización y la Ley de Justicia y Paz en cifras, <www.web .presidencia.gov.co/sp/2010/julio/24/16242010.html>, 12 February 2012.

48) Case D-6032, Judgment C-370/06, July 13 2006, Constitutional Court of Colombia.

49) Case Orlando César Caballero Montalvo, desmobvilizado del Bloque Élmer Cárdenas de las AUC, Case No. 26.945, Decision No 26.94511, July 2007, Supreme Court.

50) One of the cases that established the regime of reparations of the JPL was Case 28.769, $11 \mathrm{de}$ diciembre de 2007, modified by on 23 May 2008, Supreme Court.

51) Case 29.560, 28 May 2008, Supreme Court.

52) Case 31.539, 31 July 2009, Supreme Court and Case 28.040, 23 August 2007, Supreme Court. 
The overturning of Wilson Salazar's (aka "el Loro") sentence, showed how different the National Prosecutor's Office, the Justice and Peace Tribunals and the Supreme Court understood the objectives and procedural considerations of the law. ${ }^{53}$ This problem was solved only after the Justice and Peace Tribunals, following the Supreme Court's considerations on the overturning decision, created a protocol to be used by all these organisms involved in the judicial process. The protocol changed the strategy, and required to obtain and analyze both the background and the specific information of each case to establish a macro and a micro understanding of them. This new strategy and the burden of handling a significant number of cases with insufficient institutional resources, have caused serious delays on the proceedings. ${ }^{54}$ According to official data, in 31 December 2011 there were only 9 cases already adjudicated..$^{55}$

Additionally, there are doubts about the efficacy on the application of the law when analyzing the level of achievement of two of its main objectives: peace and reparation. At the theoretical level, peace was the main justification for the detriment of justice when justifying the law. However, after six years of the law's operation the achievement of this objective is less than clear. The rearmament of previously demobilized groups and the emergency of new criminal organizations in the regions and spaces left by the paramilitaries, show the insufficient accomplishment of this goal..$^{56}$

Regarding reparations, the recent promulgation of the Victims' law, a broad framework of administrative reparations, can also be seen as the failure of the reparations' scheme of the Justice and Peace law. The slowness of the judiciary process has delayed reparations and the scarcity of resources to cover the demand allow to affirm that the rights of the victims to reparation have not been effectively guaranteed under the Justice and Peace Law scheme. ${ }^{57}$

53) Case Wilson Salazar ( $a k a$ El Loro), 18 August 2009, Criminal Chamber of the Supreme Court of Colombia. In this sentence the Supreme Court annulled the first JPL conviction, of Wilson Salazar, considering that conspiracy to commit a crime was a "vital and essential" part of belonging to the AUC and must be part of a conviction.

54) Interviews conducted during the fieldwork developed in Colombia between October 2010 and March 2011. Diaz, supra note 34.

55) Unidad Nacional de Fiscalías para la Justicia y la Paz, Gestión Unidad Nacional de Fiscalías para la Justicia y la Paz, <http://www.fiscalia.gov.co/justiciapaz/index.htm>, 18 January 2012.

56) These 'emerging' groups are known as BACRIM. The CNRR has researched this issue and documented a large amount of information on these groups. Comisión Nacional de Reparación y Reconciliación, Disidentes, Rearmados y Emergentes: ¿Bandas Criminales o Tercera Generación Paramilitar? (CNRR, Bogotá, 2007).

57) Catalina Díaz y Camilo Bernal, 'El diseño institucional de reparaciones en la Ley de Justicia y Paz: una evaluación preliminar', in Catalina Díaz et al. (eds.) Reparar en Colombia: los dilemas en contextos de conflicto, pobreza y exclusión (Centro Internacional para la Justicia Transicional y Centro de Estudios de Derecho, Justicia y Sociedad, Bogota, 2009). Also see: International Crisis Group, Corregir el Curso: Las Victimas de la Ley de Justicia y Paz en Colombia. Informe sobre América Latina N²9-30 (International Crisis Group, Bogotá, 2008). 
In addition to reparations, victims have also been integrated and acknowledged through their participation in the proceedings. According to official data, there are more than 54000 victims who have participated in the process. ${ }^{58}$ However, some NGOs have said that although the official data show great figures, it is minimal in relation to the real number of victims that should have been involved in the process. ${ }^{59}$ They also mentioned the lack of coordination among official institutions and the limited access to information for their effective participation. ${ }^{60}$

With regards to the main achievements of the JPL law, defenders argue that without the implementation of the law and the revelations given by the applicants in the free depositions, it would have been impossible to obtain all the information provided to the victims. In fact, there are nearly 33499 facts confessed by ex members of paramilitary groups that have allowed to find the location of mass graves and the fate or whereabouts of thousands of disappeared persons. ${ }^{61}$

It has also facilitated the "visibilization" of victims (Pizarro, 2009), since the environment created by the law has generated the emergence of many victims' organizations and the consolidation of the existing ones. However, some sectors have pointed out that this is not a consequence of the law, but an international trend consolidated by the work of NGOs and national victims' organizations. ${ }^{62}$

The analysis of the national legal framework shows that Colombia has combined pardon (Law 1106) and criminal-retributive approaches (Justice and Peace Law) to deal with past crimes. In both cases, we have seen the limitations of an excessive focus on one paradigm to the expenses of other approaches to justice. This trend is reinforced by institutions with high symbolic value, as the ICC, a role that we will analyze in the next part.

\subsection{The International Level: the International Criminal Court}

The ICC is one of the main representatives at the international level of the retributive justice approach and one of the main influences at the national level on the

58) Unidad Nacional de Fiscalías para la Justicia y la Paz, Gestión Unidad Nacional de Fiscalías para la Justicia y la Paz, <http://www.fiscalia.gov.co/justiciapaz/index.htm>, 16 January 2012.

59) International Crisis Group, supra note 57.

60) Ibid. Also during the direct observation of the process in Colombia, we observed some difficulties on the effective participation of victims, such as the limitations in the way they communicated and made questions during the hearings and also on the access of victims to the place where the proceedings were taking place due to economic, geographical and time constrains.

61) Unidad Nacional de Fiscalías para la Justicia y la Paz, Gestión Unidad Nacional de Fiscalías para la Justicia y la Paz, <http://www.fiscalia.gov.co/justiciapaz/index.htm>, 17 January 2012.

62) Michael Reed, 'Transitional Justice Under Fire: Five Reflections on the Colombian Case', in Michael Reed and Amanda Lyons, (eds.), Contested Transitions: Dilemmas of Transitional Justice in Colombia and Comparative Experience (International Center for Transitional Justice, Bogota, 2010) pp. $87-114$. 
implementation of transitional justice mechanisms in Colombia. As a matter of fact, the Rome Statute created the ICC in 1998 to prosecute perpetrators of war crimes, crimes against humanity and genocide (since the crime of aggression has not been defined yet). In Colombia it has jurisdiction since November $2002^{63}$ for crimes against humanity and genocide and since November 2009 for war crimes, when the deadline of the delay declaration for this crime ended. ${ }^{64}$

The ICC's jurisdiction is regulated by the principle of complementarity, laid down under article 17 of the Rome Statute, and according to which, priority is given to the States to assure accountability for the crimes over which the ICC has jurisdiction. Nonetheless, the latter may turn out operative if the state "is unwilling or unable genuinely to carry out the investigation or prosecution". The Statute has developed in fact specific criteria to determine whether there is unwillingness and inability behind a national prosecution. ${ }^{65}$

The relationship between the ICC and Colombia is meaningful for both parties. On the one hand, Colombia represents a difficult case for the ICC, since this country has implemented a criminal policy to deal with past crimes, in contrast to the other cases under the ICC's evaluation where prosecutions were not even proposed. On the other hand, for Colombia, the ICC represents the most compelling institution to trigger criminal prosecutions. These factors, together with the ongoing conflict, made the relation between Colombia and the ICC even more complex.

As previously noted, in 2002, when the ICC was starting to operate as an international judicial body, Colombia began a peace process with the AUC. After a period of initial contacts the ICC decided to open the Preliminary Examination

63) Law 742 of 5 June 2002 was enacted to introduce the Rome Statute to the national legislation. Also see the Constitutional Court decision on the matter C-578, 2002.

64) Rome Statute of the ICC, Ratification (with Declarations), Colom., para. 5, 5 August 2002, 2194 U.N.T.S. 523, <www.treaties.un.org/pages/ViewDetails.aspx?src=TREATY\&mtdsg _no=XVIII-10\&chapter=18\&lang=en>, 17 December 2011.

65) Such criteria are regulated by Article 17 (2) (3) of the Rome Statute, which states as follows:

2. In order to determine unwillingness in a particular case, the Court shall consider, having regard to the principles of due process recognized by international law, whether one or more of the following exist, as applicable:

(a) The proceedings were or are being undertaken or the national decision was made for the purpose of shielding the person concerned from criminal responsibility for crimes within the jurisdiction of the Court referred to in article 5;

(b) There has been an unjustified delay in the proceedings which in the circumstances is inconsistent with an intent to bring the person concerned to justice;

(c) The proceedings were not or are not being conducted independently or impartially, and they were or are being conducted in a manner which, in the circumstances, is inconsistent with an intent to bring the person concerned to justice.

3. In order to determine inability in a particular case, the Court shall consider whether, due to a total or substantial collapse or unavailability of its national judicial system, the State is unable to obtain the accused or the necessary evidence and testimony or otherwise unable to carry out its proceedings; 
of the Colombian case in 2006. Currently, the ICC keeps the examination at that stage and maintains a permanent monitoring of the situation. ${ }^{66}$

To understand the influence of the ICC in the Colombian process, and the decisions made by the government to deal with past crimes, it is necessary to analyze the way in which the ICC has related to Colombian actors. In fact, there are historical milestones of this relation that can be classified as direct and indirect contacts between both actors. In the first group we can find all the official and public contacts between the ICC and the Colombian representatives, and in the second group, there are all the non-official and informal contacts. This distinction is meaningful because it reflects the problem of the inconsistency and lack of clarity of the messages of the ICC and its effects at the national level.

On the one hand, it is possible to establish a link between the direct contacts and a prudent but at the same time, ambiguous message. In this first group we can include the Colombian negotiation and posterior ratification of the Rome Statute, the Prosecutor's Office monitoring of the Colombian situation ${ }^{67}$ the decision to open the Preliminary Examination, the official visits and communications of the Prosecutor to Colombia ${ }^{68}$ and the Colombian responses to the Prosecutor's demands. All these contacts have been official and generally have been made public.

In contrast to the direct contacts, it is difficult to make a list of indirect contacts because usually they were not public. As examples we can mention, the meetings of the Prosecutor with judges, prosecutors and representatives of the

66) International Criminal Court, Communications, Referrals and Preliminary Examinations, $<$ http://www.icccpi.int/Menus/ICC/Structure+of +the+Court/Office+of+the+Prosecutor/ Comm+and+Ref/>, 21 February 2012.

67) The first direct approach was on March 2005 when the Prosecutor sent a letter to the Colombian government requesting information about the draft law that was going to be considered by the Parliament. Letter from Luis Moreno Ocampo to the Colombian Ambassador in The Hague, Francisco Jose Lloreda, transcribed in El Nuevo Siglo of 15 2008, Corte Penal Internacional Hace Requerimientos a Gobierno Uribe, <www.elnuevosiglo.com.co/noticia.php>, 12 December 2011.

68) The ICC Prosecutor has visited the country in two opportunities. In the first visit on October 2007, he asked about the steps taken by the authorities to investigate and prosecute those most responsible for crimes against humanity committed in Colombia since 2002. International Criminal Court, ICC, Prosecutor Visits Colombia, Media Advisory ICC-OTP-20071018-254-En of 18 October 2007, <http://www.icccpi.int/menus/icc/press\%20and\%20media/press\%20releases /2007/otp\%20media\%20advisory_\%20icc\%20prosecutor\%20visits\%20colombia?lan=en-GB>, 20 December 2011. During this visit the Chief Prosecutor had meetings with government officials, judges and prosecutors. In the second visit in August 2008 the Prosecutor investigated the extraditions of 15 former paramilitaries being tried under the Justice and Peace Law to the United States of America in May 2008 and the parapolitics scandal. The Spanish prosecutor Baltazar Garzón joint him and they participated in an exhumation by the Technical Investigations Corps of the General Prosecutor's Office in Uraba. He also met with senior officials from the Government, the Prosecutor's Office and the Supreme Court of Justice as well as representatives of Colombian civil society. International Criminal Court, ICC prosecutor visits Colombia, Press Release of 21 August 2008, <www.icc-cpi.int/press/pressreleases/414.html>, 27 December 2011. 
executive branch, as well as non-public speeches of the Prosecutor during his visits. In these contacts, the Prosecutor has shown a complacent attitude regarding the situation in Colombia. ${ }^{69}$ Even though there are no records or documents of some of the informal interchanges that took place during those meetings, we have obtained information from the interviews we conducted in the fieldwork. According to the information gathered, the ICC's Prosecutor has been clear stating that Colombia is making an overwhelming effort, even beyond what the Court would expect. Besides, ICC's representatives advised national judges to avoid conducting extensive and deep judicial proceedings, and to better focus on specific crimes to issue the maximum number of sentences. ${ }^{70}$

The differentiation between direct and indirect contacts is important to explain why actors in Colombia have constructed completely different interpretations of the ICC's perception of the Colombian situation and consequently, why they have different expectations about the ICC's role. On the one hand, the Colombian government believes that Colombia has made more than what is expected by the ICC and that it even constitutes an example for other countries when implementing a "positive complementarity" approach. According to the government, thus, it would not be possible to consider an intervention of the ICC in Colombia. On the other hand, some human rights activists and victims' organizations believe that the ICC's intervention is possible and even imminent, considering that Colombia has failed to address accountability during the process of demobilization and has perpetuated impunity.

In both cases, we can observe an overemphasis on the ICC's role and the model it represents. Different authors have considered the potential positive effects of the ICC's intervention in Colombia, ${ }^{71}$ idealizing the ICC and dismissing the great potential of national actors to change their own system. Accordingly, there is an overestimation of what the ICC can do for Colombia, and as an indirect

69) In contacts not directly related to Colombia, the Prosecutor has made a comparison to other cases where they have opened an investigation, showing that are not comparable to the Colombian situations where an institutional framework has been created to address violations:

"When I took office, Colombia and the DRC were the gravest situations under our jurisdiction. The difference between the two was that Colombia was and is conducting national proceedings against guerrilla leaders, paramilitaries and their political supporters, and in some cases against members of the Police, the Army and Congress, which required further analysis by my Office."

"We are regularly visiting Colombia to follow the progress of proceedings. The Colombian authorities have committed to genuinely investigating and prosecuting the crimes themselves in order to avoid our intervention. We continue to assess domestic proceedings."

Luis Moreno-Ocampo, 'The International Criminal Court - Some Reflexions', 12 Yearbook of International Humanitarian Law (2009) pp. 3-12.

${ }^{70)}$ Interviews conducted during the fieldwork developed in Colombia between October 2010 and March 2011. Diaz, supra note 34.

71) Jennifer Easterday, 'Deciding the Fate of Complementaity: A Colombian Case Study', 26 Arizona Journal of International \& Comparative Law (2009) pp. 50-111. 
consequence there is also an overrepresentation of retributive justice as the only way to deal with past crimes.

As we have noted before, the over emphasis on the retributive approach is evident not only in the interpretations of the ICC's role, but also in the approaches to justice and the strategies that the government has chosen to implement transitional justice. $^{72}$

It should be mentioned, though, that the emphasis on International Criminal Law is not only due to the ICC, but to the large institutional structure at the international level that supports this trend. In Colombia, the adaptation of national legislation to the new trends of International Criminal Law, took place even before the adoption of the Rome Statute. ${ }^{73}$ However, this concern about complying with international standards has become even deeper after the creation of the ICC.

The ambiguity generated by the unclear position of the ICC and the limitations of the retributive model at the national level pose the problem of the limits of retributive criminal justice to deal with exceptional situations, involving mass victimisation. These scenarios require more complex and refined strategies that include a broader spectrum of approaches to justice.

\subsection{Problems and Difficulties of this Approach}

The question remains though whether the national Colombian prosecutorial process, with its reduced alternative sentences, is respectful enough of the Rome Statute's interests and standards. Despite some theoretical assumptions and scarce practical experiences, today, many questions remain without answer, and only the historical trajectories of the ICC will draw the path towards a better understanding of correlative dynamics between national mechanisms, like the Colombian one, and the ICC. However, as some have noted, given the normative and factual existence of mechanisms in Colombia, it would be difficult to conclude that Colombia lacks of will and ability to prosecute, and therefore, justify an eventual intervention of the ICC..$^{74}$ In fact, unlike some African cases that lack of a normative framework to prosecute the most responsible of mass atrocities, Colombia counts with a consolidated normative process, though a particular one. This being said, the ICC keeps an eye open on the actual implementation of the JPL process and its intervention remains a possible outcome.

\footnotetext{
72) Aponte mentioned about the implementation of the Rome Statute to the national legislation that there is not a problem regarding the length of the legislation. Alejandro Aponte, 'Colombia', in: Kai Ambos and Ezequiel Malarino (eds.), Persecución penal nacional de crimenes internacionales en América Latina y España (Konrad-Adenauer-Stiftung, Montevideo, 2003.

73) Ibid.

74) Kai Ambos, Procedimiento de la Ley de Justicia y Paz (Ley 975 de 2005) y Derecho Penal Internacional. Estudio sobre la facultad de intevencion complementaria de la Corte Penal Internacional a la luz del denominado proceso de "justicia y paz» (GTZ, Ed Temis, Bogotá, 2010).
} 
But still, even if the case has been admissible under article 17, the provision on "interest of justice" provides the Prosecutor with discretionary decision to evade an investigation that "would not serve the interests of justice". ${ }^{75}$ As Valinas rightly notes, "cases of ongoing conflict as in Colombia have a special resonance in the question of the interpretation of Article 53. The urgent need to end the conflict for, above all, humanitarian reasons lends a special weight to the perception of the role of the ICC in such situations". ${ }^{76}$ The peace vs. justice debate comes into light when thinking of the eventual intervention of the ICC during the ongoing Colombian conflict. How would the remaining illegal armed groups in Colombia react towards the intervention of the ICC? As Pizarro notes, disarming to be prosecuted, without being military beaten, has not been a common historical feature; in fact, the paramilitaries constitute the first example of an illegal armed group that gave up weapons in such circumstances to enter into a peace process which included a prosecutorial process involving prison sentences, although alternative lowered ones. ${ }^{77}$ Undoubtedly, finding a negotiated solution with the remaining illegal armed groups in Colombia under the era of the ICC, will definitely nurture the complex debate on justice vs. peace, and notably raise significant questions on the meaning and interpretation of the concept of justice, which takes us to foresee the applicability of "alternative ways of doing justice", such as restorative justice, under the unpredictable shadow of the ICC.

\section{Beyond Retribution; Any Space for a Restorative Approach in Colombia?}

After having attempted to analyse the complex correlation between traditional criminal justice and the Colombian transitional justice process, we consider appropriate to go further this exercise and question ourselves, relevant and indispensable questions regarding the very meaning of justice, which has been already designed and oriented by the international community towards a narrowly legal and retributive understanding. Despite the dominant character of retributive justice at the international sphere, there are many arguments against the eventual intervention of the ICC, particularly in sensitive and challenging contexts of ongoing conflicts involving illegal armed groups, like the Colombian one.

In our opinion, before thinking of a possible intervention of the ICC in the Colombian transitional justice process, we should reflect on vital questions such as: what would the international retributive vision of justice constructively achieve in the midst of an ongoing conflict? To what extend would international

\footnotetext{
75) Article 53 of the Rome Statute.

76) Marta Valinas, 'Interpreting complementarity and interests of justice in the presence of restorative- based alternative forms of justice', in Carsten Stahn and Larissa van den Herik (eds.), Future Perspectives on International Criminal Justice (T.M.C. Asser Press, The Hague, 2010).

77) Pizarro, supra note 4.
} 
justice meet the needs and interests of suffering Colombia? Is the ICC giving priority to the needs and interests of Colombians and its peaceful future over the interests of the legal international network, or vice versa? Would the ICC contribute to better deal with the issues of transitional justice: truth, accountability, reparation and reconciliation? ${ }^{78}$ Is there any space for "alternative forms of justice", such as restorative justice under the era of the ICC?

Although restorative justice has been particularly developed in contexts that exclude large-scale mass abuses, this vision of justice has progressively, albeit scarcely, drawn the attention of intellectuals and practitioners working in the field of transitional justice. ${ }^{79}$ Restorative justice, an emerging approach within the criminological sciences that intends to find solutions to the dominant conventional justice system, offers a consistent and innovative vision of justice based on the substantive goal of restoring the harm that has been caused by an offense without the intention of inflicting punishment, ${ }^{80}$ whether applied to common crimes in times of peace or to serious violations of human rights during transitional justice contexts.

Colombia has certainly developed great interest in restorative justice as a tool to improve and complement the traditional retributive criminal system; not only the concept has been introduced in the Colombian Political Constitution and in the Code of Criminal Procedure, but it has been thought as a better way of dealing with the issues of mass victimization caused by the internal ongoing conflict. The attempt towards introducing a restorative approach into the Colombian transitional justice framework was clearly seen through the government's draft bill on alternative sentencing, which intended to replace prison sentences for other forms of accountability. Nevertheless, as we have previously explained, the law on alternative sentencing was rapidly withdrawn since it was somehow assimilated to a form of impunity. Along these lines, Gomez considers the alternative sentencing law "a bill that, with vague references to restorative justice, in reality sought to guarantee impunity for the demobilized paramilitaries". ${ }^{81}$

Moreover, a Colombian civil society initiative, accompanied with the political support of the previous government, expressed its interest on restorative justice by organizing an international symposium on "Restorative Justice and Peace in Colombia" that took place in Cali, on February 2005. During the symposium an

\footnotetext{
78) Parmentier, supra note 16.

79) Elmar Weitekamp et al., 'How to Deal with Mass Victimization and Gross Human Rights Violations. A Restorative Justice Approach', in Uwe Ewald and Ksenija Turkovic (eds.), Large-Scale Victimization as a Potential Source of Terrorist Activities - Importance of Regaining Security in PostConflict Societies (IOS Press, Amsterdam, 2006) pp. 242-252.

80) Lode Walgrave, 'Restorative Justice: An Alternative for Responding to Crime?', in Shlomo G. Shoham et al. (eds.), International Handbook of Penology and Criminal Justice (Taylor \& Francis, CRC Press, Oxford, 2008) pp. 613-689.

81) Gomez, supra note 2.
} 
extraordinary South African delegation exposed their transitional justice process, and notably, their experience with the famous South African TRC. Surprisingly, though, and despite such interest on restorative justice, this vision of justice did not receive the acceptance and reception one could have expected.

Although the JPL and the global Colombian transitional justice process do have restorative justice elements, ${ }^{82}$ the presence and shadow of the ICC, as well as the strong lobbying activity of the advocates of retributive justice, amongst other reasons, must have had a great impact in the decreasing role of restorative justice in Colombia. However, this vision of justice remains of great importance to the Colombian transitional justice process whose future might be brightened.

Since the ICC constitutes a legal-retributive approach we will analyse on the one hand, some limitations of retributive approaches in dealing with the issues of mass victimization in Colombia, and on the other hand, some possible advantages of applying instead "alternative forms of justice", such as restorative justice, which takes us to reflect on the possible dialogue between the ICC and alternative ways of doing justice.

\subsection{Limits of a Retributive Approach in Dealing with the Issues of Mass Victimization in Colombia}

679 680

Despite the big difference between dealing with common or ordinary crimes and serious violations of human rights, the way in which national and international criminal tribunals deal with the issues of mass abuses is very much based on the system used by national criminal trials to deal with ordinary crimes. ${ }^{83}$ Such structural "transplant", which is also applied by the ICC, does not go without difficulties.

Firstly, criminal trials are frequently subject to widespread critics such as being too long, expensive, inhospitable, exclusive, complex and above all, unable to meet the needs of victims, offenders and the communities. In fact, as restorative justice advocates argue, criminal trials have somehow taken the conflict away from the people involved in it $^{84}$ and failed "to engage and empower those most directly affected by crime". ${ }^{85}$ Such criticisms could be the consequence of a justice system that has been particularly conceived to inflict punishment to offenders; a

\footnotetext{
82) Pizarro, supra note 4.

83) As Drumbl notes, "the structure, rules, and methodologies of the process and punishment of extraordinary international criminality constitute a transplant of the structure, rules and methodologies of ordinary criminal process and punishment in those states that dominate the international order. Certain adaptations have taken place along the way”. Mark A. Drumbl, Atrocity, Punishment and the Law (Cambridge University Press, Cambridge, 2007).

84) Nils Christie, 'Conflicts as Property', 17 British Journal of Criminology (1977) pp. 1-15.

85) Jennifer L. Sawin and Howard Zehr, 'The Ideas of Engagement and Empowerment', in Gerry Johnstone and Daniel W. Van Ness, (eds.), Handbook of Restorative Justice (Willan Publishing, Devon, 2007) pp. 41-58.
} 
justice system that has somehow left behind the reparation and reintegration of the traumatic harm of victims and offenders. ${ }^{86}$ Surprisingly enough, the victim case scenario does not ameliorate in cases of massive crimes, principally in processes before ad hoc international criminal tribunals. ${ }^{87}$

As to the issue of accountability, a vital question arises: who and how should be held accountable for mass atrocities? In the mist of conflicts, national or international conventional justice systems will hold accountable for past atrocities a number of select guilty perpetrators, leaving behind many individuals who massively contributed to the boost of violence. As Fletcher and Weinstein note "trials do not address the complicity of those who stood by or cheered a vicious leader or who elected a war criminal to represent them" ${ }^{88}$ Undoubtedly, accountability is one of the most controversial issues of the transitional justice process in Colombia. As Bueno demonstrates in her thesis, victims and offenders of the Colombian conflict consider that massive atrocities wouldn't have taken place without the collaboration and support of thousands of human beings working directly or indirectly, and for various different reasons, towards the development of the conflict. According to them, the Colombian conflict is not limited to the illegal armed groups, but covers a vast range of variables and indirect offenders without whom the conflict would have never reached such dimensions.

Interestingly, some members of the Colombian indigenous communities argue that the roots of the conflict could be based on a disrespectful Western mentality. Correspondingly, Eliecer, a member of the Arhuacan indigenous community, explains in his own words the way in which they have been brutalized for more than 500 years by this mentality,

For more than 500 years we have been victimised physically and mentally by various actors, call them Catholic missionaries, colonizers, settlers, peasants, guerrillas, paramilitaries and delinquents, all of them inflamed by their needs, in one way or another ended with the peace in our territory, amputating our rights as a community. ${ }^{89}$

\footnotetext{
86) Isabella Bueno's doctoral thesis (unpublished work), which deeply illustrates the opinions and perceptions of victims and offenders about the traumatic experience of the conflict and the difficulties implied to heal the harm and reintegrate into society;

87) According to Llewellyn and Howse, "[c]riminal prosecutions, particularly of the kind being undertaken at The Hague, in fact offer very limited opportunity for victims to tell their stories and be heard with respect and sympathy". Jennifer Llewellyn and Robert Howser, 'Institutions for restorative justice: The South African Truth and Reconciliation Commission' 49 University of Toronto Law Journal (1999) pp. 355-388. As a matter or fact, both ad hoc international criminal tribunal for the Former Yugoslavia and for Rwanda didn't offer a space for the victims to heal their harms and respectfully participate in the process. However, fortunately, the ICC put an end to these limitations; henceforth, besides being able to participate in their personal capacity, victims are allowed to claim reparation before the ICC.

88) Laurel E. Fletcher and Harvey M. Weinstein, 'Violence and Social Repair: Rethinking the Contribution of Justice to Reconciliation', 24 Human Rights Quarterly (2002) pp. 573-639.

89) Bueno, supra note 86.
} 
In addition, victims and offenders of the Colombian conflict consider the Colombian state responsible for its institutional absence and inability to offer economic and social opportunities to the poor, and for being unable to fight against the corrupted politicians who haven't ceased from stealing the nation's public funds, and who have collaborated and financed the phenomenon of paramilitarism, together with chief generals, policemen and business men. According to paramilitary chief, Freddy Rendon Herrera, known as "El Aleman", the Colombian state should assume its responsibility for having participated hand by hand with the paramilitaries during the conflict. In his words,

for 46 years the politicians of this country haven't been able to find a solution to a conflict that pushed me to take weapons and break the law and the constitution, and be here today assuming a responsibility that I must assume. But today, that institution that has been unable to find a solution to the problem, pretends to prove to the world and to the Colombian society that we are responsible for everything,

ironically, Freddy continues,

today, the police agents, the soldiers, the politicians are not aware for example that Freddy was a member of the Autodefensas present in the north of Choco, in the Caribbean; the policemen didn't see me, the soldiers didn't see me, the politicians were not aware, the mayors didn't realise, the town councillors never met us. But I saw them all, I met them all, I spoke to all of them, I worked with all of them jointly...90

Moreover, Colombians have a strong opinion against the role of some NGOs that have financed and defended the actions of guerrillas, and the international community, particularly the developed countries, that have financed the Colombian drug business. Along these lines, a victim of kidnapping by the ELN, argues that "the drug consumers, mainly the social ones, the NGOs defending these groups - guerrilla groups -, the weapon producers who gain so much money and cause so much prejudice, are equally responsible; they are active actors that consciously cause harm because they want to cause it. And there are passive guilty ones, like the local authorities that allow this to happen and corruption; corrupted authorities are guilty for omission, the other ones are guilty for action. I am amazed by the tolerance towards the consumption of drugs, it's amazing, amazing, you see it everywhere, it's amazing; each person that consumes drugs is killing someone, is killing someone physically!". ${ }^{91}$ In fact, the international 753 dimension of the conflict frustrates Colombians. Not only they consider devel754 oped countries guilty for the damages occurred in the Colombian territory, but

\footnotetext{
90) Ibid.

91) Ibid.
} 
an eventual solution to the conflict. ${ }^{92}$ In the words of a victim of displacement, "the conflict of drugs goes beyond Colombia; it has been brought by other countries, they are the ones with the financial resources and the negotiators; they are the main source of the problem. They should accept that they are guilty of our country's harm"..$^{33}$

As a result, exclusive retributive accountability may leave behind an unpleasant perception susceptible of affecting many transitional justice processes. ${ }^{94}$ Although today there is a widespread agreement according to which conflicts are made of massive invisible forces that have benefited from the conflict and encouraged it, criminal trials still work on the basis of exclusive retributions that can only increment division to the expenses of unification, and may therefore hamper the path towards reconciliation.

Further, those exclusively chosen perpetrators would be held individually accountable for massive collective crimes. ${ }^{95}$ In the words of Fletcher and Weinstein, "because the criminal justice system addresses only individual accountability for criminalized acts, the evidence from social psychologists forces us to rethink the question of collective responsibility". ${ }^{96}$ Surprisingly, international retribution, which is practically limited to imprisonment, doesn't take into account the collective dimension of conflicts.

And still, even when prosecutions have been chosen to deal with mass atrocities, one must be sure if they are really feasible and/or worth it. Besides the abovementioned political difficulties prosecutions may imply, there are additional barriers such as the huge number of eventual defendants and the excessive cost of international trials. Even at the international level that counts with financial support, prosecutions do not go without further logistical, and even ethical, complications; in addition to the difficulties related to "catching up" the offenders, and the barriers due process may pose, the experience of both the ICTY and the ICTR has proven to be exorbitantly expensive and long. This critical situation has triggered some to consider the reconstruction of national legal systems a better choice than the expensive prosecution of some offenders $\left.{ }^{\left({ }^{7}\right.}\right)$. Along the same lines, according to the report of the Secretary General

\footnotetext{
92) Ibid.

93) Ibid.

94) Drumbl, supra note 83. The negative effects of exclusive retributive forms of accountability are well described by Drumbl's strong statement according to which "for many Rwandans and Bonsian Muslims, retribution might well include accountability for the UN and foreign governments, whose peacekeepers were ineffective while genocidal massacre occurred in their midst".

95) This principle of individual responsibility for collective crimes has been applied by international criminal law and reaffirmed by article 25 of the ICC statute.

96) Fletcher and Weinstein, supra note 88.

97) Naomi Roth-Arriaza, 'The New Landscape of Transitional Justice', in Naomi Roht-Arriaza and Javier Marriezcurrena, (eds.), Transitional Justice in the Twenty-First Century; Beyond Truth versus Justice (Cambridge University Press, New York, 2006) pp. 1-16.
} 
$[\mathrm{u}]$ nfortunately, the international community has not always provided rule of law assistance that is appropriate to the country context. Too often, the emphasis has been on foreign experts, foreign models and foreign-conceived solutions to the detriment of durable improvements and sustainable capacity.9

Frequently, advocates for prosecution argue that criminal trials aim at preventing future human rights violations, constitute a historical memory and encourage peace and reconciliation. In our opinion, though, meeting such goals in an ongoing conflict seems far from being a reality; paradoxically, criminal trials may even pose obstacles to achieving these goals.

Regarding deterrence, we argue that although criminal trials may have a censure effect over gross violations of human crimes, they do not necessarily deter offenders from committing these crimes. As Aukerman rightly notes, "it is virtually impossible to assess whether or not the threat of prosecution has ever prevented genocide and war crimes". ${ }^{99}$ Certainly, the presence of national and/or international criminal trials has not prevented suicide bombers from committing atrocities, neither actual guerrilla members in Colombia to continue their illegal activities.

Even in cases of eventual deterrence, we join Aukerman's point of view according to which "it is unlikely that post-atrocity prosecution is the most effective way to prevent future atrocities". ${ }^{100}$ According to the victims and offenders of the Colombian conflict, mass atrocities will continue to occur as long as they do not find a solution to the causes of the conflict, particularly corruption, the lack of social and economical opportunities to all citizens, and above all, the drug business. In sum, national and international prosecutions may have the positive effect of censuring an atrocity and set a precedent, but, on the one hand, they do not constitute the unique censuring instrument, and on the other hand, they do not necessarily deter from committing mass atrocities, particularly in cases of ongoing conflict, like the Colombian one, in which criminal structures are so well consolidated and the conflict per se has become such a profitable business.

As to the key issue of truth, in our opinion, since prosecutions intent to inflict punishment over the guilty offender, the concept of truth would be particularly used to achieve this goal. In other words, prosecutorial truth would aim at unveiling the truth behind a crime to determine the offender's degree of culpability, and therefore, leave behind the truth containing the explanations of the occurrence of mass atrocities. We join therefore the vision of some authors who argue that "the truth that is revealed in court trials, international and national, is a fragmented fact finding process to serve as evidence in proving or refuting guilt, but never to

\footnotetext{
98) Report of the Secretary General, supra note 15.

99) Miriam J. Aukerman, 'Extraordinary Evil, Ordinary Crime: A Framework for Understanding Transitional Justice', 39 Harvard Human Rights Journal (2002) pp. 39-97.

100) Ibid.
} 
bring out the truth of the conflict as a social phenomenon. Trials do not allow perpetrators or survivors to produce a story that might coincide and lead to an explanation of the causes of the conflict" ${ }^{101}$ Moreover, according to many offenders of the Colombian conflict, despite the calming and healing effect telling the truth may have, the threat of punishment has deterred many offenders from telling the truth about the crimes they have committed. ${ }^{102}$

With regards to the issue of reconciliation it seems doubtful to consider that prosecutions can positively contribute to a process of reconciliation in a tornapart society. In fact, "there have been virtually no studies that systematically have attempted to examine or measure the contribution of trials to reconciliation and social reconstruction" ${ }^{103}$ We could even go further to consider that prosecutions could hamper the road towards reconciliation, at least in situations of ongoing conflict. As Bueno has thoroughly demonstrated in her thesis, one of the main reasons why offenders from the guerrillas haven't demobilised is precisely the fear of being locked up in prisons. ${ }^{104}$

Uganda also provides an example of such difficult case scenario; despite the claims of the Achioli community according to which the eventual intervention of the ICC would obstruct peace efforts, the prosecutor of the ICC issued arrest warrants against the LRA leadership, conducing the LRA to respond by a rejection of ending the war in presence of the arrest warrants. ${ }^{105} \mathrm{In}$ fact, the delicate and even undesirable consequences of an eventual intervention of the ICC in situations of ongoing conflicts raises relevant questions regarding its legitimacy and real utility, which, in our opinion, shouldn't be ignored by the field of transitional justice. In fact, as Shaw and Waldorf rightly note, "as the heated public controversy over the International Criminal Court's involvement in Uganda indicates, the current phase of transitional justice is frequently marked by disconnections between international legal norms and local priorities and practices". ${ }^{106}$ Moreover, although we believe reconciliation between victims and offenders shouldn't be forced by any transitional justice mechanism, we do not consider convenient to incite negative and even hatred emotions susceptible of further bridging the gap between the parties. Accordingly, Llewellyn and Howse argue that

\footnotetext{
101) Weitekamp et al., supra note 79.

102) Bueno, supra note 86.

103) Fletcher and Weinstein, supra note 88.

104) Bueno, supra note 86.

105) Sverker Finnstrom, 'Reconciliation Grown Bitter? War, Retribution, and Ritual Action in Northern Uganda', in Rosalind Shaw et al (eds.), Localizing Transitional Justice: Interventions and Priorities After Mass Violence (Stanford University Press, Stanford, 2010) pp. 135-156.

106) Rosalind Shaw and Lars Waldorf, 'Introduction: Localizing Transitional Justice', in Rosalind Shaw et al (eds.), Localizing Transitional Justice: Interventions and Priorities After Mass Violence (Stanford University Press, Stanford, 2010) pp. 3-26.
} 
the paradigmatic, isolating, or alienating methods of retribution seem totally self-defeating for one cannot restore a relation of equality between the members of society by removing one party in the relationship (the perpetrator) from society altogether, whether by execution, banishment, or imprisonment. ${ }^{107}$

Further, such excluding process may pose great barriers for the proper reintegration of the offender and therefore for him/her personal and family reconciliation.

Additionally, what about traditional mechanisms integrating culturally based ways of doing justice? According to some,

[w]e cannot assume that legal justice is desired or the highest priority in all countries after periods of repression or violence. Culture and history may lead to different definitions of justice and to different paths for achieving it; justice can be defined broadly, and retributive justice is only one part of that definition. ${ }^{108}$

Since transitional justice at the international level has been almost exclusively focused on a legal approach, particularly with the creation of the permanent ICC, countries going through transitional processes may be tempted to avoid implementing their culturally based mechanisms in order to align to the standards of international criminal justice, and therefore, avoid an eventual request of the ICC on the basis of the principal of complementarity. Consequently, the inconvenience is twofold: on the one hand, countries may lose interest in studying and probably implementing a rich variety of indigenous and local-level mechanism that may serve for inspiration to the western world and provide a cultural richness to the country, and on the other hand, the legal approach would gain force to the expenses of other ways of doing justice.

Moreover, history has shown an international community that has not always equally taken into account all extraordinary events. As Christie explains while referring to the Nuremberg trials and the atrocities of world war II, "by hanging commanders, and while the judges in Nuremberg focused on finding personal guilt for atrocities, other phenomena were left in peace, left to grow. Three themes were not discussed in Nuremberg: - Dresden - Hiroshima and Nagasaki - The Gulags". ${ }^{109}$ The sensitive selection of extraordinary cases is particularly questioned nowadays under the era of the ICC, which has mainly focused on African conflicts to the expenses of others conflicts.

107) Llewellyn and Howser, supra note 87.

108) Harvey M. Weinstein, Laurel E. Fletcher, Patrick Vinck and Phuong N. Pham, 'Stay the Hand of Justice: Whose Priorities take Priority?', in Rosalind Shaw et al (eds.), Localizing Transitional Justice: Interventions and Priorities After Mass Violence (Stanford University Press, Stanford, 2010) pp. 27-48.

109) Nils Christie, 'Answers to Atrocities. Restorative Justice in Extreme Situations', in Ezzat A. Fattah and Stephan Parmetier (eds.), Victim Policies and Criminal Justice on the Road to Restorative Justice - Essays in Honor of Tony Peters (Leuven University Press, Leuven, 2001) pp. 379-392. 
So retributive approaches, either national or international, do not seem to have a very clear and coherent purpose; according to Drumbl, even "judges still remain unsure, and often divided, about the purpose of the punishment they mete out". ${ }^{110}$ One could even ask if the justice practitioners are not being dominated by the system itself. In fact, as national trials have been criticized for being unable to meet the needs and interests of the parties involved in the process, "[s]imilar problems will arise if transitional justice reflects only the priorities of the international community and not those of the affected country". ${ }^{111}$ All these critical aspects leads us to consider prosecutions a simple way of avoiding exploring the real truth and complexities behind a conflict; it may be easier to point out the "bad" guys than assuming a broader concept of responsibility; a concept that may rightly involve the massive number of individuals, states, political groups, NGOs, national and international organizations that, massively, participated in the occurrence of mass victimization.

\subsection{Restorative Justice; an Option in Dealing with an Ongoing Conflict}

Whether applied to ordinary crimes during times of peace, or to crimes of serious and massive nature in transitional justice contexts, restorative justice offers a vision of justice that pretends to elucidate the way in which criminality should be dealt with; restorative justice, thus, by means of a critical analysis on the weaknesses of existing visions of justice, particularly on the dominant retributiveoriented approach, offers solutions susceptible of being applied during times of peace and/or war. Although it has been particularly developed in relation to ordinary crimes, this vision of justice has progressively entered the discourse of transitional justice. But still, despite the blooming growth of restorative justice and transitional justice as independent fields of study, little has been said about the coalition of both. Nevertheless, advocates of restorative justice seem to agree upon the potential significant role it could play in addressing severe cases. Along these lines, Stovel argues that approaching transitional justice from a restorative perspective would be beneficial since

[i]t is the form of justice most directly concerned with reconciliation. It addresses the reintegrative needs of both victims and most perpetrators. In poor countries with weak judicial systems, it offers an alternative to lengthy and expensive trials. And in much of Africa, it draws on pre-existing restorative justice traditions and institutions. ${ }^{112}$

110) Drumbl supra note 83.

111) Aukerman supra note 99.

112) Laura Stovel, When the Enemy comes Home: Restoring Justice after Mass Atrocity, Restorative Justice Conference, Vancouver, June 1-4, 2003 <www.sfu.ca/cfrj/fulltext/stovel.pdf>, 29 March 2012. 
The question of the application of restorative justice in cases embracing systematic political violence has been raised largely as a result of the influential work of the renowned South African Truth and Reconciliation Commission and Rwandan "gacaca courts"; Nonetheless, although both mechanisms have been originally tainted with restorative overtones, they do also comprise non restorative-oriented elements, and even retributive shades, like gacaca's accountability measures. ${ }^{113}$ In fact, the scarce literature on the coalition of restorative justice and transitional justice refers to the existing mechanisms of transitional justice, but hasn't gone further to build a solid framework about this fusion. Given such literature gap, we will briefly present our understanding of restorative justice through Bueno's model, and the way in which this vision of justice could penetrate the field of transitional justice.

\subsection{Toward a Model of Restorative Justice}

Fig. 1 pretends to illustrate our vision of restorative justice (see Fig. 1).

According to this model, a model of justice would be restorative if the follow-

1. Restorative justice, is based on a restorative philosophy consisting of, on the one hand, the principle of non-violence and the principle of interconnectedness, and on the other hand, of underlying values such as respect, humility, solidarity and love. In this sense, the restorative justice model and the restorative philosophy share both the same values;

2. The restorative justice model is based on a "restorative rule of law" system that includes all harms and is not only limited to the crimes that have been established by law. Therefore, according to restorative justice, focus is made "on the harms of wrongdoing more than the rules that have been broken". ${ }^{114}$

3. The primary goal of restorative justice is the restoration of the harm of victims, offenders and communities. Other goals, such as forgiveness, apology, trust, and reconciliation, are ideal and essential goals of restorative justice, but remain secondary;

\footnotetext{
113) On the one hand, despite the TRC's deep restorative elements, such as the space provided to victims to be heard and acknowledged, the possibility of providing a broader explanation about the past and a form of accountability based on truth and not retribution, trust building would have required "white South Africans to take responsibility and atone for their support for apartheid - it would require full restorative justice" Ibid. On the other hand, Gacaca courts provide a concrete example of a mixture of restorative and retributive elements: "confessions and accusations, plea bargains and trials, forgiveness and punishment, community service and incarceration" Shaw and Waldorf, supra note 106.

114) Mark Umbreit and Marilyn Peterson (eds.), Restorative Justice Dialogue: An Essential Guide for Research and Practice (Springer Publishing Company, New York, 2010).
} 
Primary Goal: To Restore the Harm and Reintegrate the Offender

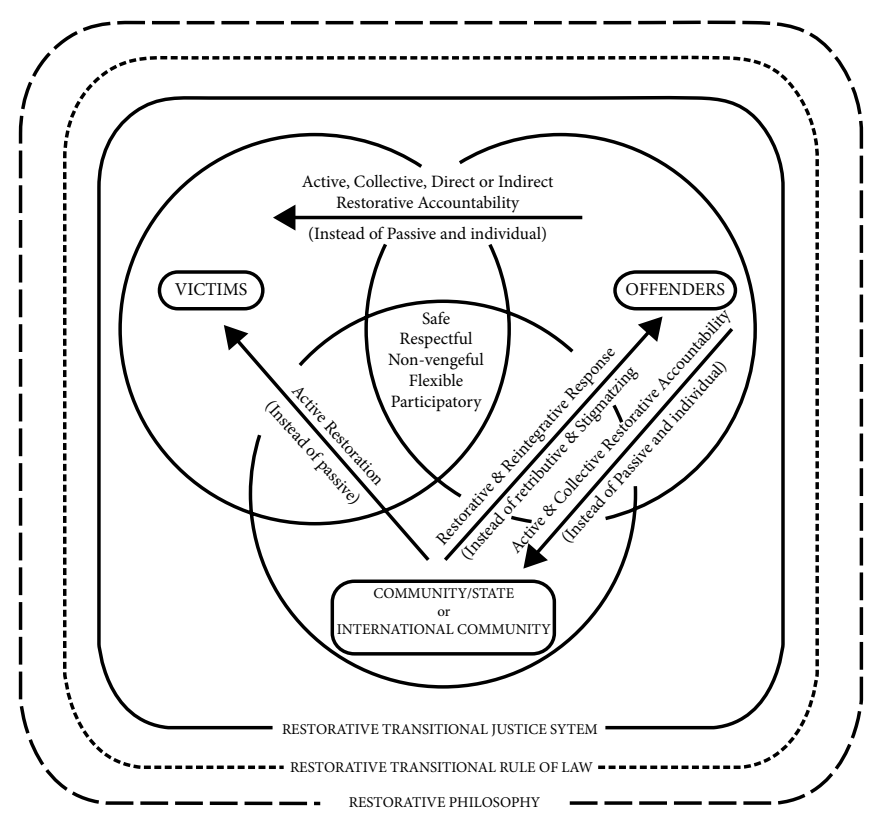

Secondary Inter-related Goals: Trust and Reconcilation

${ }^{\star}$ Reconcillation amongst the members of the group

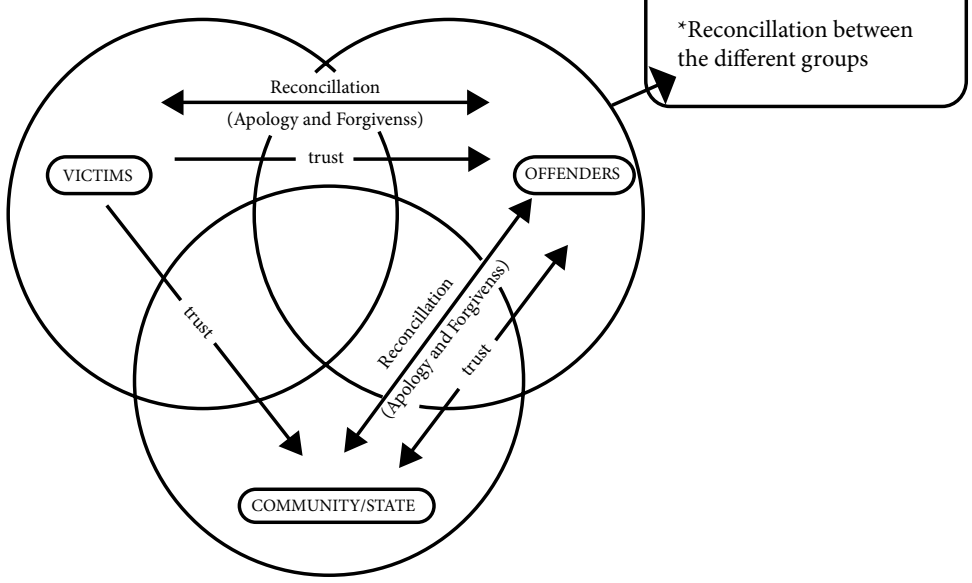

Figure 1. Restorative Justice in times of normality. 
4. Restorative accountability: In restorative justice the community/state should intent to restore the harm of the victim and the harm of the offender. The latter, in exchange, should intent to actively participate in the restoration of the victim's harm, the community's harm and his/her harm. Coercive measures, such as restorative imprisonment should be taken place only if necessary and without the intention of punishment infliction; ${ }^{115}$

5. The process of restorative justice should be flexible enough to meet the needs of victims, offenders and communities. It should therefore "provide opportunities for dialogue, direct or indirect, between victims and offenders as appropriate"; ${ }^{116}$

6. The state should be present throughout the restorative justice process to guarantee security, the respect of human rights and the right execution of decisions taken either by a judge or mediator or collectively by the interested parties;

7. The whole process should be governed with respect and without any form of revengeful attitudes.

After having presented our understanding of the theory of restorative justice with regards to ordinary crimes we will now explain how this vision of justice can penetrate the field of serious violations of human rights. We should clarify though, that the concept of restorative justice is understood in exactly the same way as it has been explained, meaning an approach of justice that intents to restore the harm. The difference resides, though, in the context in which we pretend to analyse the application of restorative justice: a context of transitional justice involving massive crimes. The restorative approach would therefore need to adapt itself to the characteristics that involve mass victimization, meaning a collective dimension due to the elevated number of victims and offenders and the international dimension of the international community, which is obviously concerned by the gravity of the crimes. Accordingly, the model of restorative justice in transitional justice contexts, or as we have called it, "restorative transitional justice", would look in the following way:

The question of "restorative transitional justice" could be defined as "the variety of processes and mechanisms established to restore, to the extent possible, the individual and social harm caused by mass abuses". ${ }^{117}$ International, national and/ or local-level transitional justice mechanisms may only gain the restorative adjective if they embrace the above mentioned restorative elements. In other words, neither truth commissions nor traditional justice mechanisms are inherently restorative; a real restorative transitional justice mechanism would be the one that

115) Walgrave, supra note 80.

116) Umbreit and Peterson, supra note 114.

117) Bueno, supra note 86. 
1013 tantly, since group offenses involve many perpetrators, dialogue and group 1014 truth-telling processes should take place to better construct a recording memory 1015 of the past.

1016 Restorative accountability in transitional justice would avoid any form of 1017 intentional punishment infliction and connect accountability to restoration 1018 and reintegration through measures like truth, community service, symbolic 1019 actions, compensation, among others. Like with restorative truth, restorative 1020 transitional justice should provide the opportunity for offenders to collectively 1021 restore the direct and/or indirect victims' and social harm. We subscribe therefore 1022 to Arsovska, Valinas and Vanspauwen's argument according to which transitional 1023 justice should require "a broad understanding of accountability which goes 1024 beyond mere individual responsibility. 'Accounting' for a violent past will include 1025 not only a recognition of what happened and the responsibilities associated to it, 1026 but also a commitment to make up for those wrongs and to prevent them in the 1027 future". ${ }^{119}$

118) Truth and Reconciliation Commission of South Africa, Report, 5 vol., Vol. 1. (Juta Publishers, Cape Town,1998).

119) Jana Arsovska et al., 'From micro to macro, from individual to state: restorative justice and multi-level diplomacy in divided societies', in Ivo Aertsen et al. (eds.), Restoring Justice after largescale violent conflicts: Kosovo, DR Congo and the Israeli-Palestinian Conflict (Willan Publishing, Devon, 2008) pp. 444-460. 
As to the issue of reconciliation, we argue that the justice system of transitional justice societies must intent, to the extent possible, to respect the larger goal of national peace and reconciliation; a goal that goes beyond the justice system and touches every citizen of the ragged society; a necessary goal that, in our opinion, will be better met and respected through restorative justice, to the expenses of the conventional legalistic vision of justice. As previously mentioned, there has always been a conflict between peace and justice. However, as rightly said by UN Secretary-General Ban Ki-moon "the debate on how to 'reconcile' peace and justice or how to 'sequence' them has lasted more than a decade. Today, we have achieved a conceptual breakthrough: the debate is no longer between peace and justice but between peace and what kind of justice" ${ }^{120}$ In contrast to the retributive dimension of the conventional justice system that threatens the goal of peace and reconciliation, "restorative justice offers a means of resolving this peace vs. justice dilemma"; ${ }^{121}$ restorative justice proposes a vision of justice that respects this indispensable goal and softens the road to achieve it. In Aukerman's words, "both retributive and restorative justices envision reconciliation as a product of full accountability for wrongdoing. But while retributive accountability involves proportionate punishment, restorative accountability demands an acknowledgement by offenders of their culpability and a willingness to make good. While retributive justice allow society to punish an offender as a means of achieving reconciliation, restorative justice requires society to include the offender in the process of reconciliation". ${ }^{122}$ In our opinion, the justice system must bend over peace and reconciliation, which is a necessary and urgent state of a conflictridden society, and not the opposite.

\section{Conclusions}

Through this article we pretended to highlight some of the limitations of the dominant retributive approach when dealing with the issues of transitional justice in Colombia, particularly in a complex context of ongoing conflict that involves consolidated illegal armed groups disposing of extraordinary financial means from the drug business. Given such inconveniences, we presented the restorative justice model as possible justice approach susceptible of bringing about solutions to the good administration of the issues of transitional justice.

\footnotetext{
120) Valentina Torricelli, The Contribution African States Can Make to the ICC Review Conference, $<$ www.africanarguments.org/2010/03/11/the-contribution-african-states-can-make-to-the-icc -review-conference/>, 29 February 2012.

121) Paul McCold, et al., An Introduction to Restorative Peacebuilding. Briefing Paper 1. Restorative Peacebuilding Project. Working Party on Restorative Justice (Alliance of NGOs on Crime Prevention and Criminal Justice, New York, 2007).

122) Aukerman, supra note 99.
} 
1060 Today, though, the uncertainty remains as to the attitude of the ICC towards 1061 national restorative transitional justice mechanisms. Could a country, experienc1062 ing an ongoing conflict, deal with the issues of transitional justice in a purely 1063 restorative way under the era of the ICC? Would it be forced to create retributive 1064 justice mechanisms to avoid an intervention of the latter? Only time and experi1065 ence will illuminate the dialogue between the ICC and the restorative justice 1066 approaches.

1067 Nevertheless, as we have previously explained, Colombia has done an effort in 1068 establishing state organised transitional justice mechanisms which intent to com1069 ply with the ICC's demands while trying to achieve peace. In fact, these mecha1070 nisms may be tainted by the retributive or the restorative justice approach or by a 1071 mixture of both. For example, whereas the judicial process of the JPL contain 1072 elements of both approaches, other mechanisms, like those established by Law 10731106 contain to certain degree some restorative elements.

1074 However, as previously explained, the discourse and the theory of transitional 1075 justice in Colombia has been mainly dominated by the retributive approach to 1076 justice, due in great part, to the presence and shadow of the ICC, which considers 1077 criminal justice as the only response to mass atrocity and the only way to avoid 1078 impunity in this scenario. We argue, though, that the excessive focus on this 1079 approach has dismissed other possible approaches to justice that may consider1080 ably enrich the field of transitional justice.

1081 We consider, thus, that the ICC should be prudent enough with those coun1082 tries that couldn't find a solution to their conflicts before the ratification of the 1083 Rome Statute. In the particular Colombian case, which is actually dealing with 1084 the issues of mass victimisation during a very complex conflict situation, the ICC 1085 should only exercise a guiding role intended to contribute to the consolidation of 1086 the Colombian national justice mechanisms, which may obviously integrate a 1087 restorative justice oriented approach. 